\title{
Gender, environment and history: New methods and approaches in environmental history
}

RUTH A. MORGAN

The Australian National University, Canberra

MARGARET COOK

University of the Sunshine Coast, Sunshine Coast

\section{Abstract}

We are far from the first, and expect we will not be the last, to wonder at the paucity of research on women, gender and sexuality in (Anglophone) environmental history. To borrow from Virginia Scharff, who was writing in 1999, environmental history still has a 'sex secret'. For all the insights of feminist scholarship, science studies, queer studies, women's history, gender history and histories of sexuality that have accumulated since then, many environmental historians still seem to find 'forest fires more fascinating than cooking fires', at least in Australia and the United States. Yet historical studies of women's garden making, environmental and animal welfare movements, domestic labour, knowledge making, 'alternative' environments and mountaineering (just to name a few areas of dynamic scholarship) show that women have indeed been agents of environmental change in ways that either conformed to or contested contemporary gender and sexual expectations. Arising from the 'Placing Gender' workshop held in Melbourne in 2018, this collection brings together four contributions that demonstrate different approaches to undertaking gender analysis in environmental history. Focusing on non-Indigenous women and men in the Anglo-world from the mid-nineteenth century, some adopt new tools to excavate familiar terrain, while others listen closely to voices that have been rarely heard in the field. Recasting the making of settler places in terms of their gendered production and experience not only enriches their own environmental history, we argue, but also broadens the historian's enquiry to encompass the other lands implicated in the production of settler places.

Keywords: environmental history, gender history, colonial history, historical geography

As we write, the British Government has embarked on an ambitious vaccination program in an effort to curb the worst COVID-19 outbreak in Europe. Living in the first country to begin vaccinating its population, over 100,000 Britons number amongst the estimated 2.25 million people around the world who have died as a result of contracting the disease. Following the path of disasters and diseases past, COVID-19 has exposed and exacerbated the nature and extent of all manner of socioeconomic 
inequalities, such that some people are bearing the brunt of the pandemic more heavily than others. ${ }^{1}$ Environmental historian and COVID-19 survivor Marco Armiero puts it bluntly: 'the entire epidemic apparatus unveils the truth about a system built to reproduce privilege through normalising injustice. ${ }^{2}$ In the United Kingdom and the United States, for example, racial and environmental injustices have rendered some peoples of colour particularly vulnerable to the disease, ${ }^{3}$ with research among the latter finding that the largest average percentage increase in numbers of deaths compared with previous years among Hispanic people (53.6 per cent) and the smallest among whites (11.9 per cent). ${ }^{4}$ Public health responses to the pandemic, meanwhile, have shone a spotlight on the weaknesses of a precarious labour force, as well as the classed, gendered and racialised nature of paid and unpaid health care, domestic labour and sanitation. Furthermore, economic stress has combined with restrictions on movement outside the home to increase gender-based violence, as evidenced by increased demand for support services. ${ }^{5}$

Historians counsel that COVID-19 is no 'natural' disaster. Rather, it is of our own making. As the environmental historian Liza Piper reminds us, 'We cannot lose sight of the coronavirus as part of us: our relationships with one anotherunequal, divergent, and connected-are the "nature" that is integral to this and every pandemic'. ${ }^{6}$ Although the precise origins of the disease are not yet certain, environmental historians can already see how the forces of globalisation, urbanisation, industrialisation and industrial agriculture have rendered us increasingly interconnected - not just with each other through trade and travel, but also with animals and the atmosphere through pathogens and pollution. ${ }^{7}$

\footnotetext{
1 The authors are grateful to the anonymous reviewers for their feedback, which has strengthened this essay. For an Australian perspective, see K. Holmes, 'Generation COVID: Crafting History and Collective Memory', Griffith Review 71 (2021), www.griffithreview.com/articles/generation-covid.

2 M. Armiero, 'COVID-19, the World, and Me', in 'Reflections: Environmental History in the Era of Covid-19', Environmental History 25, no 4 (2020): 682, doi.org/10.1093/envhis/emaa053.

3 N. Bhala et al., 'Sharpening the Global Focus on Ethnicity and Race in the Time of COVID-19', Lancet 395 (2020), doi.org/10.1016/S0140-6736(20)31102-8; J. Kopel et al., 'Racial and Gender-based Differences in COVID-19', Frontiers in Public Health 8 (2020), doi.org/10.3389/fpubh.2020.00418.

4 L. M. Rossen et al., 'Excess Deaths Associated with COVID-19, by Age and Race and Ethnicity-United States, January 26-October 3, 2020', Morbidity and Mortality Weekly Report 69, no. 42 (2020): 1522-7, doi.org/ 10.15585/mmwr.mm6942e2.

5 J. S. Chandan et al., 'COVID-19: A Public Health Approach to Manage Domestic Violence is Needed', Lancet: Public Health 5, no. 6 E309 (2020), doi.org/10.1016/S2468-2667(20)30112-2.

6 L. Piper, 'Pandemic Relations', in 'Reflections: Environmental History in the Era of Covid-19', Environmental History 25, no 4 (2020): 650, doi.org/10.1093/envhis/emaa053.

7 See R. Peckham, 'COVID-19 and the Anti-Lessons of History', Lancet 395 (2020): 850-2, doi.org/10.1016/ S0140-6736(20)30468-2; T. van Dooren, 'Pangolins and Pandemics: The Real Source of this Crisis is Human, Not Animal', New Matilda, 22 March 2020, newmatilda.com/2020/03/22/pangolins-and-pandemics-the-real-sourceof-this-crisis-is-human-not-animal, accessed 4 February 2021; G. Thomas and G. Lachenal, 'COVID-19: When History Has No Lessons: Facing a Crisis Without Precedent', Public Seminar, 6 April 2020, publicseminar.org/ essays/covid-19-when-history-has-no-lessons, accessed 4 February 2021; K. Brown, 'The Pandemic is Not a Natural Disaster', New Yorker, 13 April 2020, www.newyorker.com/culture/annals-of-inquiry/the-pandemic-is-not-anatural-disaster, accessed 4 February 2021; K. Hao and M. Hicks, 'What Past Disasters Can Teach Us About How to Deal with COVID-19', MIT Technology Review, 15 April 2020, www.technologyreview.com/2020/04/15/999509/ mar-hicks-interview-previous-disasters-can-teach-us-about-covid-19, accessed 4 February 2021.
} 
What and how we breathe, long concerns for residents of industrialising regions and countries, had already become a cause for alarm across southern and eastern Australia as bushfires and smoke swept across the continent in the Savage Summer of 2019/20. Those who could escaped with their families to unaffected areas, while many more made do with masks and sought refuge indoors. Even as the embers cooled across nearly 19 million hectares of land, the largest area burnt in a single recorded fire season in eastern Australia, the human and ecological toll continued to mount along the familiar fault-lines of gender, race, class and geography. ${ }^{8}$ The bushfires disproportionately affected Aboriginal people in New South Wales and Victoria, for example, where they comprise nearly 5.4 per cent of the people living in fire-affected areas, but only 2.3 per cent of the total state populations. ${ }^{9}$ Across the scorched continent, some among the affected were yet to be born, as bushfire smoke is detrimental to maternal health, the placenta and the unborn child. ${ }^{10}$ It continued to circle the globe weeks after the fires were finally extinguished in early March. ${ }^{11}$

COVID-19 and the Australian bushfires feature among the array of 'hotspots' that are proliferating and escalating across the globe in the Anthropocene. ${ }^{12}$ We point to the bushfires simply because we both live and work in Australia; we could just as easily have described 2020's fires in the Amazon rainforest, the Siberian heatwave, or flooding and landslides in Vietnam and Cambodia. Just as postcolonial, Marxist and feminist scholars have argued, these hotspots have made a lie of this so-called 'Age of Humans' for, as Rob Nixon has noted, 'We may all be in the Anthropocene but we're not all in it in the same way.' ${ }^{13}$

Critiques of the misnomer of the Anthropocene abound, premised on the historical structures, systems, inequalities and possibilities that the term elides and obfuscates. Although the resulting litany of alternative '-ocenes' are both generative and speculative, the Anthropocene itself has a 'silver lining', as the geographer Laura

8 L. Richards et al., '2019-20 Australian Bushfires—Frequently Asked Questions: A Quick Guide', Parliamentary Library Research Paper (Canberra: Parliament of Australia, 2020), www.aph.gov.au/About_Parliament/Parliamentary_ Departments/Parliamentary_Library/pubs/rp/rp1920/Quick_Guides/AustralianBushfires, accessed 4 February 2021. 9 B. Williamson et al., Aboriginal Peoples and the Responses to the 2019-2020 Bushfires, CAEPR Working Paper 134/2020 (Canberra: ANU, 2020).

10 S. Vardoulakis et al., 'Lessons Learned from the Australian Bushfires: Climate Change, Air Pollution, and Public Health', JAMA Internal Medicine 180, no. 5 (2020), doi.org/10.1001/jamainternmed.2020.0703.

11 National Institute of Water and Atmospheric Research (NIWA), 'Media Release: Bushfire Smoke Continues Trip Around the World', 23 April 2020, niwa.co.nz/news/bushfire-smoke-continues-trip-around-world, accessed 4 February 2021.

12 G. Mitman, 'The Unruliness of a Virus', in 'Reflections: Environmental History in the Era of Covid-19', Environmental History 25, no 4 (2020): 642, doi.org/10.1093/envhis/emaa053.

13 For critiques of the Anthropocene, see D. Chakrabarty, 'The Climate of History: Four Theses', Critical Inquiry 35, no. 2 (2009): 197-222; A. Malm and A. Hornborg, 'The Geology of Mankind? A Critique of the Anthropocene Narrative', Anthropocene Review 1 (2014): 62-9, doi.org/10.1177/2053019613516291; D. Haraway, 'Anthropocene, Capitalocene, Plantationocene, Chthulucene: Making Kin', Environmental Humanities 5, no. 1 (2015): 159-65; J. W. Moore, 'The Capitalocene, Part I: On the Nature and Origins of Our Ecological Crisis', Journal of Peasant Studies 44 (2017): 594-630, doi.org/10.1080/03066150.2016.1235036; P. Star, 'The letter: Leaving the Anthropocene, entering the Nemescene', International Review of Environmental History 4, no. 1 (2018): 5-6, doi.org/10.22459/IREH. 04.01.2018.02; R. Nixon, 'The Anthropocene: The Promise and Pitfalls of an Epichocal Idea', in Future Remains: A cabinet of curiosities for the Anthropocene, ed. G. Mitman et al. (Chicago: University of Chicago Press, 2018), 8. 
Pulido suggests, because it 'forces us to reckon with history'. ${ }^{14}$ For Pulido, the uneven racial geography of the Anthropocene demands closer historical analysis, while the feminist anthropologist Anna Tsing questions the single universalising narrative or timeline that the Anthropocene implies. ${ }^{15}$ These critiques align with those who highlight the dominance of male 'Northern voices' in planetary science circles, such that the Anthropocene might be more accurately dubbed the 'Manthropocene'. ${ }^{16}$ In this 'hegemonic Anthropocene narrative', Stefania Barca argues, 'the forces of production (science and industrial technology) are maintained as the only possible tool for understanding the errors and for repairing them. The system itself is not under question; its gender, class, spatial and racial inequalities are either invisible or irrelevant: no paradigm shift is necessary'. ${ }^{17}$

Whether environmental historians consider the Anthropocene an analytically useful device for their work is a moot point: the field of environmental history, as J. R. McNeill reminds us, is a 'very big tent'. ${ }^{18}$ What we are drawn to as environmental historians is the way these wider debates about the Anthropocene's nomenclature and framing reflect disciplinary challenges and conversations within the field regarding representation, practice and structures of power. ${ }^{19}$ Three decades after Carolyn Merchant's provocative 1990 article on gender and environment in the Journal of American History, the field of environmental history is reckoning with its overwhelmingly white, heteronormative, male canon..$^{20}$ Again.

We are far from the first, and expect we will not be the last, to wonder at the paucity of research on women, gender and sexuality in (Anglophone) environmental history. ${ }^{21}$ To borrow from Virginia Scharff, who was writing in 1999, environmental

14 L. Pulido, 'Racism and the Anthropocene', in Future Remains, ed. Mitman et al., 124.

15 A. L. Tsing, 'A Feminist Approach to the Anthropocene: Earth Stalked by Man', Helen Pond McIntyre '48 Lecture, Barnard College, New York, 18 December 2015, www.youtube.com/watch?v=ps8J6a7g_BA, at 6.30, accessed 4 February 2021.

16 K. Raworth, 'Must the Anthropocene be a Manthropocene?', Guardian, 20 October 2014, www.theguardian. com/commentisfree/2014/oct/20/anthropocene-working-group-science-gender-bias, accessed 26 March 2021. See also, S. McGregor and N. Seymour, 'Introduction', RCC Perspectives: Men and Nature-Hegemonic Masculinities and Environmental Change 4 (2017): 9.

17 S. Barca, Forces of Reproduction: Notes for a Counter-Hegemonic Anthropocene (Cambridge: Cambridge University Press, 2020)

18 J. R. McNeill, 'Observations on the Nature and Culture of Environmental History', History and Theory 42, no. 4 (2003): 6.

19 See, for example, 'Inside Dish: Mary E. Mendoza on Thinking Outside the Box', Environmental History Now, 13 September 2019, envhistnow.com/2019/09/13/inside-dish-mary-e-mendoza-on-thinking-outside-the-box/\#_ ftn2, accessed 4 February 2021; N. Langston et al., The Syllabus Project (2019), thesyllabusproject.weebly.com, accessed 4 February 2021.

20 C. Merchant, 'Gender and Environmental History', Journal of American History 76, no. 4 (1990): 1117-21.

21 See, for example, M. Leach and C. Green, 'Gender and Environmental History: From Representation of Women and Nature to Gender Analysis of Ecology and Politics', Environment and History 3 (1997): 343-70; N. Unger, Beyond Nature's Housekeepers: American Women in Environmental History (New York: Oxford University Press, 2012); N. Langston, 'Thinking like a Microbe: Borders and Environmental History', Canadian Historical Review (2014): 592-603; M. Carey, 'Latin American Environmental History: Current Trends, Interdisciplinary Insights, and Future Directions', Environmental History 14 (2009): 221-52, doi.org/10.1093/envhis/14.2.221. We regret that our survey of the field does not extend to scholarship published in languages other than English. As a result, we have likely overlooked important contributions in other languages as well as those in allied disciplines. 
history still has a 'sex secret' ${ }^{22}$ For all the insights of feminist scholarship, science studies, queer studies, women's history, gender history and histories of sexuality that have accumulated since then, many environmental historians still seem to find 'forest fires more fascinating than cooking fires', at least in Australia and the United States. ${ }^{23}$ Scharff's wit points to the scales, spaces, practices and subjects that continue to dominate historical analysis, in which the kinds of ecological transformations that women past have wrought are deemed too mundane, too small, too feminine to be significant. Yet historical studies of women's garden making, environmental and animal welfare movements, domestic labour, knowledge making, 'alternative' environments and mountaineering (just to name a few areas of dynamic scholarship), show that women past have indeed been agents of environmental change in ways that either conformed to, or contested, contemporary gender and sexual expectations. ${ }^{24}$

22 V. Scharff, 'Man and Nature! Sex Secrets of Environmental History', in Human/Nature: Biology, Culture and Environmental History, ed. J. P. Herron and A. G. Kirk (Albuquerque: University of New Mexico Press, 1999), $31-48$.

23 Scharff, 'Man and Nature!', 37. For an extensive overview of the field of gender and environmental history in the United States, see N. Unger, 'Women and Gender: Useful Categories of Analysis in Environmental History', in Oxford Handbook of Environmental History, ed. A. C. Isenberg (New York: Oxford University Press, 2014), 600-28, doi.org/10.1093/oxfordhb/9780195324907.013.0021. For an incisive review of feminist approaches to sustainability and environmental history, see T. B. Voyles, 'Man Destroys Nature? Gender, History, and the Feminist Praxis of Situating Sustainability', in Sustainability: Approaches to Environmental Justice and Social Power, ed. J. Sze (New York: NYU Press, 2018), 196-221.

24 In addition to the US scholarship (to 2014) cited by Unger, 'Women and Gender: Useful Categories of Analysis in Environmental History', see, for example, R. Ellis, Vertical Margins: Mountaineering and the Landscapes of Neo-imperialism (Madison: University of Wisconsin Press, 2001); K. Holmes, " In Spite of it All, the Garden Still Stands”: Gardens, Landscapes and Cultural History', in Cultural History in Australia, ed. H-M. Teo and R. White (Sydney: UNSW Press, 2003), 173-85; C. Jordan, 'Progress versus picturesque: White women and the aesthetics of environmentalism in colonial Australia 1820-1860', Art History 25, no. 3 (2003): 341-57; A. Gaynor, 'Animal Husbandry and House Wifery? Gender and Suburban Household Food Production in Perth and Melbourne, 18901950', Australian Historical Studies 36 (2004): 238-54; A. Gaynor, Harvest of the Suburbs: An Environmental History of Growing Food in Australian Cities (Crawley: UWA Publishing, 2006); A. Hay, 'Recipe for Disaster: Motherhood and citizenship at Love Canal,' Journal of Women's History 21, no. 1 (2009): 111-34; K. Holmes, Between the Leaves: Stories of Australian Women, Writing and Gardens (Crawley: UWA Publishing, 2011); N. Prendergast, 'Raising the Thanksgiving Turkey: Agroecology, Gender, and the Knowledge of Nature', Environmental History 16, no. 4 (2011): 651-77; J. Thorpe, Temagami's Tangled Wild: Race, Gender and the Making of Canadian Nature (Vancouver: UBC Press, 2012); C. Gowdy-Wygant, Cultivating Victory: The Women's Land Army and the Victory Garden Movement (Pittsburgh: University of Pittsburgh Press, 2013); K. Sayer, “His Footmarks on Her Shoulders": The Place of Women Within Poultry Keeping in the British Countryside, c.1880 to c.1980', Agricultural History Review 61, no. 2 (2013): 301-29; A. Denning, Skiing into Modernity: A Cultural and Environmental History (University of California Press, 2014); L. K. Poole, Saving Florida: Women's Fight for the Environment in the Twentieth Century (Gainesville: University of Florida Press, 2015); W. T. Okie, 'Beauty and Habitation: Frederika Bremer and the Aesthetic Imperative of Environmental History', Environmental History 24 (2019): 258-81, doi.org/10.1093/ envhis/emy130; H. Mercer, 'Atmospheric archives: Gender and climate knowledge in colonial Tasmania', Environment and History 27, no. 2 (2021): 193-210; A. H. Moore and R. W. Sandwell (eds), 'Women and Energy', RCC Perspectives: Transformations in Environment and Society 1 (2020); R. Rice, “My dear Hooker”: The botanical landscape in colonial New Zealand', Museum History Journal 13, no. 1 (2020): 30-41; R. W. Sandwell and A. H. Moore (eds), In a New Light: Histories of Women and Energy (Kingston: McGill-Queen's University Press, 2021); K. Twigg, 'The Green Years: The role of abundant water in shaping postwar constructions of rural femininity', Environment and History 27, no. 2 (2021): 277-302. This list is by no means exhaustive, and we acknowledge there is a rich scholarship of gender, environment and history, particularly in the cognate disciplines of historical geography and history of science. 
Attending to gender and environmental history, however, is not only a matter of adding women to the scholarship, or, more precisely, recovering and reintegrating women as historical actors and agents into the stories we tell about the past. Just as environmental historians and others have long understood 'nature' as an historical category, and the environment as 'everywhere', so too 'the work of gender in history is never done', as Susan Schrepfer and Douglas Sackman reminded us a decade ago. ${ }^{25}$ Simply put, all environments and (human) bodies are gendered, as are environmental knowledge, experiences and behaviours. As Scharff observes, 'Gender, the bundle of habits and expectations and behaviours that organises people and things according to ideas about the consequences of sexed bodies, is a crucial, deep, and far-reaching medium through which we encounter nature'. ${ }^{26}$ We have only to turn to recent research in the field of environmental psychology that observed the ways in which particular environmental behaviours are construed as either masculine or feminine in Western contexts. ${ }^{27}$ Typically, behaviours that aim to minimise environmental impacts are coded feminine, and are thus undesirable to men who, in order to avoid 'effeminacy', seek to perform hegemonic masculinity.

This is familiar territory. Environmental historians have shown how Progressive Era men in the United States struggled to reconcile their 'feminine' environmental concerns, which critics had associated with an extension of women's domestic responsibilities, with upholding their masculine authority. ${ }^{28}$ Similarly, others have investigated the ways in which white male elites (and boys) used hunting, farming, ornithology and other outdoor activities to perform their masculinity in North America, British India and the Andes in the late nineteenth and early twentieth

25 S. R. Schrepfer and D. C. Sackman, 'Gender', in A Companion to American Environmental History, ed. D. C. Sackman (Malden, MA: Wiley-Blackwell, 2010), 116.

26 V. J. Scharff, 'Introduction', in Seeing Nature Through Gender, ed. V. J. Scharff (Lawrence: University Press of Kansas, 2003), xiii.

27 For example, J. K. Swim et al., 'Gender Bending and Gender Conformity: The Social Consequences of Engaging in Feminine and Masculine Pro-Environmental Behaviours', Sex Roles 82 (2019), doi.org/10.1007/ s11199-019-01061-9; A. R. Brough et al., 'Is Eco-Friendly Unmanly? The Green-Feminine Stereotype and its Effect on Sustainable Consumption', Journal of Consumer Research 43, no. 4 (2016): 567-82, doi.org/10.1093/jcr/ ucw0 44 .

28 A. Rome, "Political Hermaphrodites": Gender and Environmental Reform in Progressive America', Environmental History, 11 (2006): 440-63. For women and the Progressive era of conservation, see, for example, S. Rimby, Mira Lloyd Dock and the Progressive Conservation Movement (University Park: Pennsylvania State University Press, 2012); P. Kropp, 'Wilderness Wives and Dishwashing Husbands: Comfort and the Domestic Arts of Camping in America, 1880-1910', Journal of Social History 43, no. 1 (2009): 5-30. 
centuries. $^{29}$ Enslaved African American men undertook masculine activities of hunting and fishing, as well as cultivating the small garden plots allocated to families by slaveholders. ${ }^{30}$ Settler men forged their own strain of masculinity in the rugged Australian Mallee, while whites performed their 'manly vitality' in the exploitation of California's Salton Sea and Mexico's Huasteca. ${ }^{31}$ The harsh environments of the poles likewise provided a stage for muscular performances of Western manhood. ${ }^{32}$ In the case of the Arctic, women writers and audiences crafted these men's exploits into heroic narratives, while urban elites overlooked the quotidian labours of washerwomen in Helsinki's frigid winters. ${ }^{33}$ That environmental behaviours and

29 M. Egan, 'Wrestling Teddy Bears: Wilderness Masculinity as Invented Tradition in the Pacific Northwest', Gender Forum 15 (1996): 32-49; T. Loo, 'Of Moose and Men: Hunting for Masculinities in British Columbia, 1880-1939', Western Historical Quarterly 32 (2001): 296-319, doi.org/10.2307/3650737; K. Wonders, 'Hunting Narratives of the Age of Empire: A Gender Reading of their Iconography', Environment and History 11, no. 3 (2005): 269-91; J. Sramek, “Face Him Like a Briton”: Tiger Hunting, Imperialism, and British Masculinity in Colonial India, 1800-1875', Victorian Studies 48, no. 4 (2006): 659-80; G. Gillespie, Hunting for Empire: Narratives of Sport in Rupert's Land, 1840-70 (Vancouver: UBC Press, 2008); P. Boag, 'Thinking like Mount Rushmore: Sexuality and Gender in the Republican Landscape', in Seeing Nature Through Gender, 40-62; M. S. Reidy, 'Mountaineering, Masculinity, and the Male Body in Mid-Victorian Britain', Osiris 30, no. 1 (2015): 158-81, doi.org/10.1086/682975; B. R. Jordan, Modern Manhood and the Boy Scouts of America: Citizenship, Race and the Environment, 1910-1930 (Chapel Hill: UNC Press, 2016); G. N. Rosenberg, The 4-H Harvest: Sexuality and the State in Rural America (Philadelphia: University of Pennsylvania Press, 2016); V. R. Mandala, 'British Huntswomen in Colonial India: Imperialism and Gender Hierarchies, 1890-1921', International Review of Environmental History 6, no. 1 (2020): 71-99, doi.org/10.22459/IREH.06.01.2020.04; K. A. Greer, Red Coats and Wild Birds: Military Ornithologists and Migrant Birds Shaped Empire (Chapel Hill: University of North Carolina Press, 2020); V. P. Carroll, 'Ralph and Myrtle Mae Borsodi's vision of back-to-the-land as a white heteropatriarchal refugium during the Great Depression', Environment and History 27, no. 2 (2021): 303-30.

30 D. D. Glave, "A Garden So Brilliant with Colors, So Original in its Design”: Rural African American Women, Gardening, Progressive Reform, and the Foundation of an African American Environmental Perspective', Environmental History 8, no. 3 (2003): 395-411, doi.org/10.2307/3986201; D. D. Glave, 'Rural African American Women, Gardening, and Progressive Reform in the South', in To Love the Wind and the Rain: African Americans and Environmental History, ed. D. D. Glave and M. Stoll (Pittsburgh: University of Pittsburgh Press, 2006), 37-50, doi.org/10.2307/j.ctt5hjs5p.8. See also J. Jones, Labor of Love, Labor of Sorrow: Black Women, Work, and the Family from Slavery to the Present (New York: Basic Books, 1985); J. L. Morgan, Laboring Women: Reproduction and Gender in New World Slavery (Philadelphia: University of Pennsylvania Press, 2004); J. A. Carney, Black Rice: The African Origins of Rice Cultivation in the Americas (Cambridge, MA: Harvard University Press, 2009).

31 K. Holmes, 'Making Masculinity: Land, Body, Image in Australia's Mallee Country', RCC Perspectives: Transformations in Environment and Society, no. 2 (2017): 39-48, doi.org/10.5282/rcc/7907; T. B. Voyles, 'Toxic Masculinity: California's Salton Sea and the Environmental Consequences of Manliness', Environmental History 26 (2020): 127-41, doi.org/10.1093/envhis/emaa076; K. Holmes, 'The "Mallee-made Man": Making Masculinity in the Mallee Lands of South-Eastern Australia, 1890-1940', Environment and History 27, no. 2 (2021): 251-76; M. I. Santiago, The Ecology of Oil: Environment, Labor, and the Mexican Revolution, 1900-1938 (Cambridge: Cambridge University Press, 2006).

32 A. Howkins, 'Appropriating Space: Antarctic Imperialism and the Mentality of Settler Colonialism', in Making Settler Space: Perspectives on Race, Place and Identity, ed. T. Banivanua-Mar and P. Edmonds (Basingstoke: Palgrave, 2010), 29-52; C. Strange, 'Reconsidering the "Tragic" Scott Expedition: Cheerful Masculine Home-making in Antarctica, 1910-1913', Journal of Social History 46, no.1 (2012): 66-88, doi.org/10.1093/jsh/shs032. For a critique of the gendered past and present of polar and glaciological research, see M. Carey et al., 'Glaciers, Gender, and Science: A Feminist Glaciology Framework for Global Environmental Change Research', Progress in Human Geography 40, no. 6 (2016): 770-93, doi.org/10.1177/0309132515623368.

33 S. Laakkonen, 'A Touch of Frost: Gender, Class, Technology, and the Urban Environment in an Industrialising Nordic City', in Northscapes: History, Technology, and the Making of Northern Environments, ed. D. Jorgensen and S. Sörlin (Vancouver: UBC Press, 2013), 195-222; M. Robinson, 'Manliness and Exploration: The Discovery of the North Pole', Osiris, 30, no. 1 (2015): 89-109, doi.org/10.1086/682968. 
environments are gendered invites further analysis of the historical roots and impacts of such perceptions, and underscores the relevance of and need for the study of gender and environment in the past to understand how this legacy informs the present and future.

In addition to these historical analyses of the gendering of identities and environments, environmental historians have also turned to the materiality of the human body and the ways its very corporeality is both historically and ecologically contingent. Such embodied approaches to environmental history recognise the 'body's historicity' as a 'material and narrated' entity that defies what Christopher Sellers describes as the 'tacit boundaries of our field-between body and environment, human and nonhuman nature'. ${ }^{34}$ In colonial contexts, human bodies themselves became barometers of environmental change, which could manifest in gender and reproductive anxieties among settler populations. ${ }^{35}$ While some environments were wanting, others could be restorative, as Michael Lansing found in conservationist schemes to rehabilitate the emasculated bodies of disabled veterans after the Great War. ${ }^{36}$ Meanwhile, Nancy Langston's work probes the porosity of human and animal bodies, and the hormonal impacts of the proliferation of industrial chemicals since the 1930s. ${ }^{37}$ Among her concerns are the implications of the resulting gender transformations on reproductive health, particularly for women and wildlife, although queer and trans-feminist scholars reject the suggestion of biological or 'natural' heteronormativity. ${ }^{38}$ That such an ecological understanding of human and animal bodies emerged after the Second World War in an Anglophone context of narrowly defined gender roles has not been lost on environmental historians. Rachel

34 C. Sellers, 'Thoreau's Body: Towards an Embodied Environmental History', Environmental History 4, no. 4 (1999): 486-514.

35 See C. B. Valenčius, The Health of the Country: How American Settlers Understood Themselves and their Land (New York: Basic Books, 2002); W. Anderson, The Cultivation of Whiteness: Science, Health and Racial Destiny in Australia (Carlton: Melbourne University Press, 2002); A. Bashford, Imperial Hygiene: A Critical History of Colonialism, Nationalism, and Public Health (New York: Palgrave, 2004); L. Nash, Inescapable Ecologies: A History of Environment, Disease and Knowledge (Berkeley: University of California Press, 2007); C. L. Wiersema, 'A Fruitful Plain: Fertility on the Tallgrass Prairie, 1810-1860', Environmental History 16, no. 4 (2011): 678-99, doi. org/10.1093/envhis/emr081; J. Beattie, Empire and Environmental Anxiety: Health, Science, Art and Conservation in South Asia and Australasia, 1800-1920 (New York: Palgrave, 2011); R. A. Morgan, 'Health, Hearth and Empire: Climate, Race and Reproduction in British India and Western Australia', Environment and History 27, no. 2 (2021): 229-50.

36 M. J. Lansing, "Salvaging the Man Power of America": Conservation, Manhood, and Disabled Veterans During World War I’, Environmental History 14 (2009): 32-57.

37 N. Langston, 'Gender Transformed: Endocrine Disruptors in the Environment', in Seeing Nature through Gender, ed. Scharff, 129-66; N. Langston, Toxic Bodies: Hormone Disruptors and the Legacy of DES (New Haven, CT: Yale University Press, 2010).

38 G. di Chiro, 'Polluted Politics? Confronting Toxic Discourse, Sex Panic, and Eco-Normativity', in Queer Ecologies: Sex, Nature, Politics, Desire, ed. C. Mortimer-Sandilands and B. Erickson (Bloomington: Indiana University Press, 2010), 199-230; M. Ah-King and E. Hayward, 'Toxic Sexes: Perverting Pollution and Queering Hormone Disruption', Technosphere Magazine (2019), technosphere-magazine.hkw.de/p/Toxic-Sexes-Perverting-Pollution-andQueering-Hormone-Disruption-w19PngN1pNwssGrnNm7hmy, accessed 4 February 2020; O. Cielemęcka and C. Åsberg, 'Introduction: Toxic Embodiment and Feminist Environmental Humanities', Environmental Humanities 11 (2019), doi.org/10.1215/22011919-7349433. 
Carson looms large in this work, not least in terms of her contribution to the postwar environmental movement as a woman scientist and the gendered reception of her publications, particularly Silent Spring. ${ }^{39}$

Focusing on gendered bodies also aligns with the field's interest in labour and work as the means by which humans relate to, make sense of and impact the environment. ${ }^{40}$ Where work happens, the nature of that work, and the very bodies that work are all gendered. Take Scharff's account of unloading her groceries, for instance: a familiar and mundane chore that connects her gendered domestic labour to the gendered processes of industrial agriculture. ${ }^{41}$ Having consumed the food on Scharff's table, her family's bellies become joined to a web of commodities, themselves produced by gendered bodies (human and other-than-human), in gendered industries, in gendered environments. ${ }^{42}$ Of those commodities, dairy milk in particular has invited gendered analysis, ranging from maternal care and child-rearing, to its production, and the very dairy cows themselves. ${ }^{43}$ Gendered nouns and pronouns for animals have also been found an effective means of obscuring the industrial nature of twentieth-century livestock production, or a potential hindrance to the progress of medical research that depends on animal testing. ${ }^{44}$

39 See, for example, M. Hazlett, 'Voices from the Spring: Silent Spring and the ecological turn in American health', in Seeing Nature Through Gender, ed. V. J. Scharff (Lawrence: University Press of Kansas, 2003), 103-28; A. Rome, "'Give Earth a chance": The environmental movement and the sixties', Journal of American History 90, no. 2 (2003): 525-54; N. C. Unger, 'From Jook Joints to Sisterspace: The role of nature in lesbian alternative environments in the United States', in Queer Ecologies: Sex, Nature, Biopolitics and Desire, ed. C. Mortimer-Sandilands and B. Erickson (Bloomington: University of Indiana Press, 2010), 173-98; N. Langston, 'Rachel Carson's legacy: Endocrine disrupting chemicals and gender concerns', GAIA 21, no. 3 (2012): 225-9; R. M. Alexander, 'In defense of nature: Jane Jacobs, Rachel Carson and Betty Friedan', Journal of Women's History 31, no. 3 (2019): 78-101.

40 For the classic essay, see R. White, “Are You an Environmentalist or Do You Work for a Living?”: Work and Nature', in Uncommon Ground: Rethinking Human Place in Nature, ed. W. Cronon (New York: W.W. Norton, 1995), 171-85; more recently, see M. Armiero, 'Enclosing the Sea: Remaking Work and Leisure Spaces on the Naples Waterfront, 1870-1900', Radical History Review 109 (2011): 13-35, doi.org/10.1215/01636545-2010-013; S. Barca, 'Laboring the Earth: Transnational Reflections on the Environmental History of Work', Environmental History 19, no. 1 (2014): 3-27, doi.org/10.1093/envhis/emt099; Namrata Borkotoky, 'Locating "coolie” women's health in tea plantation environments in colonial Assam', Environment and History 27, no. 2 (2021): 211-28.

41 Scharff, 'Man and Nature!', 43-4.

42 N. Mink, 'It Begins in the Belly', Environmental History 14 (2009): 312-22.

43 K. Smith-Howard, Pure and Modern Milk: An Environmental History Since 1900 (New York: Oxford University Press, 2013); C. Hustak, 'Got Milk? Dirty Cows, Unfit Mothers, and Infant Mortality, 1880-1940', in Animal Metropolis: Histories of Human-Animal Relations in Urban Canada, ed. J. Dean et al. (Calgary: University of Calgary Press, 2017), 189-218; T. Kaarlenkaski, “Machine Milking is More Manly than Hand Milking”: Multispecies Agencies and Gendered Practices in Finnish Cattle Tending from the 1950s to the 1970s', Animal Studies Journal 7, no. 2 (2018): 76-102. For a gendered analysis of other domesticated livestock, see H. Ritvo, The Platypus and the Mermaid, and Other Figments of the Classifying Imagination (Cambridge, MA: Harvard University Press, 1997), 131-214. 44 A. T. Hajdik, 'A "Bovine Glamour Girl”: Borden Milk, Elsie the Cow, and the Convergence of Technology, Animals, and Gender at the 1939 New York World's Fair', Agricultural History 88, no. 4 (2014): 470-90; M. Klingle, 'The Multiple Lives of Marjorie: The Dogs of Toronto and the Co-Discovery of Insulin', Environmental History, 23 (2018): 368-82, doi.org/10.1093/envhis/emx134. 
Gender and sexuality not only shape historical relations between humans and the environment, but also intersect with the dynamics of race, class, place and culture. Examining the contours of these power dynamics in environmental history, as Traci Brynne Voyles suggests, invites more complex and contingent historical narratives of environmental change than those of either triumph or decline. ${ }^{45}$ ' [W] hen we refocus our attention to include women, the picture ... becomes more richly textured, more reflective of the lived experience', Marsha Weisiger contends in her study of Navajo pastoralism during the New Deal era. ${ }^{46}$ Michael D. Wise, for instance, shows how the regulation of livestock butchery at the turn of the twentieth century, which had long been the province of Blackfeet women, allowed administrators of the US Office of Indian Affairs 'to further supervise the Blackfeet's assimilation toward Anglo-American standards of gender and labor ${ }^{2}{ }^{47}$ These examples alone confirm that in the field of environmental history, gender can and does do much more than produce an 'endless rediscovery that humans have often made nature female', to paraphrase Richard White's 2001 cautionary insight on the potential contributions of ecofeminism to the field. ${ }^{48}$

Among the reasons that Scharff suggests for the relatively scant attention to women in environmental history, let alone questions of gender and sexuality, are the limitations of historical sources. Some have endeavoured to 'cover their tracks' for all manner of reasons, while others have left little trace. Micah Muscolino, for instance, recovers the gendered dimensions of soil and water conservation in 1950s China through oral history interviews with the elderly women who lived through these campaigns. ${ }^{49}$ Consider too the contemporary social prejudices that ensure some groups are more represented than others in public records, as Peter Boag and Valerie Korinek both found in their searches for historical evidence of gender and sexual transgressions in the Pacific Northwest and western Canada during the nineteenth and early twentieth centuries. ${ }^{50}$ In light of the field's growing attention to other-than-humans and their historical agency, Scharff muses: 'Women, unlike woodchucks, have the power of speech, but environmental historians have not listened very well'. ${ }^{51}$

\footnotetext{
45 Voyles, 'Man Destroys Nature?', 204.

46 M. Weisiger, Dreaming of Sheep in Navajo Country (Seattle: University of Washington Press, 2011), xviii.

47 M. D. Wise, Producing Predators: Wolves, Work and Conquest in the Northern Rockies (Lincoln: University of Nebraska Press, 2016), 59.

48 R. White, 'Afterword-Environmental History: Watching a Field Mature', Pacific Historical Review 70, no. 1 (2001): 109.

49 M. S. Muscolino, Water Aroused the Girl' Hearts: Gendering water and soil conservation in 1950s China, Research Paper No. 2019-04 (San Diego: University of California, San Diego 21st Century China Center, 2019). 50 P. Boag, Same-Sex Affairs: Constructing and Controlling Homosexuality in the Pacific Northwest (Berkeley: University of California Press, 2003); P. Boag, 'The Trouble with Cross-Dressers: Researching and Writing the History of Sexual and Gender Transgressiveness in the Nineteenth-Century American West', Oregon Historical Quarterly 112, no. 3 (2011): 322-39; V. J. Korinek, Prairie Fairies: A History of Queer Communities and People in Western Canada, 1930-1985 (Toronto: University of Toronto Press, 2018).

51 Scharff, 'Man and Nature!', 39.
} 
Nearly two decades on, the essays in this collection do listen. Using material culture, oral histories and government archives, they listen carefully to non-Indigenous women and men past to examine their gendered experiences of place-making in the temperate settler lands of Aotearoa New Zealand, Australia and Canada from the nineteenth to the twenty-first century. Settler nations all, but the particular places being made range from the rural frontier to the suburban home. So too, the subjects of these environmental histories differ widely, not only in terms of their gender identities, but also their ethnicity, ability, age, language and culture. Spanning two centuries, these essays demonstrate the fluidity of gender and sexuality over time, and the ways in which non-Indigenous women and men shaped places, and the ways these places shaped them in return.

It was not our intent for the contributions to this collection to focus on nonIndigenous women and men in settler colonies; we encourage environmental historians to engage more closely with how environmental relations between Indigenous and non-Indigenous peoples have been historically gendered, sexualised and raced, and the ways in which gender and sexuality has shaped Indigenous placemaking. On a related note, we approach this collection on gender and environmental history as a set of potential avenues for further exploration and engagement, not as a prescriptive agenda for our colleagues in the field. As Joan Scott noted in her 2008 reflection on her landmark essay: 'questions about gender can be asked and answered only in specific contexts ... like "class" it is most useful when it points the way to specific investigations of meanings, whether of social relationships or rhetorical proclamations. ${ }^{52}$

These themes of gender, race and settler colonial place-making were the subject of lively discussion at the 'Placing Gender' workshop, which was held in Melbourne on Wurundjeri country, and in Bendigo, on Dja Dja Wurrung country, in December 2018. Convened by Katie Holmes and Ruth Morgan, and supported by the Rachel Carson Center, the Australian Research Council, Monash University and La Trobe University, the workshop was a response to what we saw as the relatively underdeveloped nature of gender analysis in environmental history and the lack of attention given to it at major environmental history meetings in Europe and North America during 2017 and 2018. These concerns were raised on the White Horse Press blog in 2017, with posts from Verena Winiwarter and Ruth Morgan, and the workshop offered a means to revitalise this area of enquiry with contributions from Australasia, North America, the United Kingdom, India and China.

52 J. W. Scott, 'Unanswered questions', American Historical Review 113, no. 5 (2008): 1423, doi.org/10.1086/ ahr.113.5.1422. 
Following Haraway, the contributors take a feminist approach to their sources, understanding them as material objects themselves that are politically and culturally constituted in particular places and times. ${ }^{53}$ The quilt, the survey form and the oral testimony analysed in these essays are artefacts of situated environmental knowledge that connect their production, form and contents to a wider web of power relationships and meanings that inform their consumption and interpretation. They contain multitudes: the personal, intimate and embodied narratives of experiences and contestations of the gendered dreams and failures of imperialism, colonialism, capitalism, migration and the nation-state. Consequently, they reveal less about past material environments and environmental change than about the meanings their authors created from their own gendered experiences of making place in settler lands.

Drawing on geography's spatial insights, each contribution examines the gendered ways in which non-Indigenous women and men negotiated their own identities and belonging in unfamiliar places. In making homes for themselves in settler lands, these migrants were engaging in what Heather Goodall has elsewhere described as a 'continuing relationship, in memory and day-to-day connections, with home countries as well as with new homelands. ${ }^{54}$ Such a grounded 'translocalism' is temporal as well as spatial, and mobile as well as fixed, allowing for 'places [to] travel with the peoples through whom they are constituted', as Hugh Raffles suggests. ${ }^{55}$ It follows then that the places studied in the essays here are necessarily relational, material manifestations of particular social and environmental relations that accumulated over time and space. ${ }^{56}$

In making places for themselves, the subjects of these studies participated in and contended with prevailing settler geographies of inclusion and exclusion. For both humans and more-than-humans, belonging and inclusion in settler space and the settler polity are always contested categories mediated by social relations. ${ }^{57}$ As Adele Perry observes of nineteenth-century British Columbia, 'Gender is where the abiding bonds between dispossession and colonisation become most clear. Notions and practices of manhood and womanhood were central to the twinned businesses of marginalising Aboriginal people and designing and building a white society'. ${ }^{58}$ For settler colonial nations, such as Australia, this dispossession of Indigenous

\footnotetext{
53 D. Haraway, 'Situated Knowledges: The Science Question in Feminism and the Privilege of Partial Perspective', Feminist Studies 14, no. 3 (1988): 589.

54 H. Goodall, 'Remaking the Places of Belonging: Arabic Immigrants and the Urban Environment along Sydney's Georges River', Mirades en Movimiento 1 (2012): 69.

55 H. Raffles, 'Local Theory: Nature and the Making of an Amazonian Place', Cultural Anthropology 14 (1999): 324; K. Brickell and A. Datta, 'Introduction: Translocal Geographies', in Translocal Geographies: Spaces, Places, Connections, ed. K. Brickell and A. Datta (Farnham: Ashgate, 2011), 3-22.

56 See D. Massey, Space, Place and Gender (Hoboken: Wiley, 1994).

57 See, for example, E. O’Gorman, 'Belonging', Environmental Humanities 5, no. 1 (2014): 283-6, doi.org/ 10.1215/22011919-3615523.

58 A. Perry, On the Edge of Empire: Gender, Race and the Making of British Columbia, 1849-71 (Toronto: University of Toronto Press, 2001), 19.
} 
peoples haunts the non-Indigenous polity, whose own fears of exile inform historic and ongoing anxieties about (non-white) immigration and reproduction, thereby challenging the project of belonging for unwelcome newcomers. ${ }^{59}$

Of the papers shared in late 2018, this collection brings together four contributions that demonstrate different approaches to undertaking gender analysis in environmental history. Some adopt new tools to excavate familiar terrain, while others listen closely to voices that have been rarely heard in the field. We begin in nineteenth-century colonial Ottawa, where Vanessa Nicholas draws on the insights of art history to demonstrate the ways in which settler women's handicrafts might be read as gendered products of colonial power. Focusing on an embroidered coverlet or quilt, Nicholas contends that the floral decoration reflects a picturesque interpretation of unfamiliar lands that elides the Indigenous dispossession fundamental to British settler colonialism. Furthermore, she shows how the domestic object was a product of, and embedded in, the processes of industrialisation and trade that pulsed through the British Empire. By interpreting the quilt's production as the manifestation of the appropriation of land and resources, Nicholas demonstrates the ways in which settler women were implicated in the processes of settler colonialism in British North America.

The collection then turns to Aotearoa New Zealand, where Meg Parsons and Karen Fisher examine the gendered transformation of the Wāipa River in the Waikato and King Country districts of the North Island from the 1860s through to the 1930s. Focusing on the role of Pākehā (settler) women, Parsons and Fisher use both archival and visual sources, as well as oral histories, to understand their efforts to remove and remodel the indigenous forests and wetlands. In doing so, they challenge long-standing historical narratives that position Pākehā settler men as the sole agents of the radical environmental changes that followed formal British colonisation in 1840 . Through the lens of hegemonic masculinity and femininity they demonstrate how Pākehā gender norms informed the ways in which Pākehā men and women in this riverine area perceived their local environments, their own and others' day to day activities, and how they interacted with human and morethan-human communities.

Across the Tasman Sea, Margaret Cook analyses the challenges faced by settler farmers in central Queensland's Callide Valley in the 1930s. Her archive is the correspondence of nearly 1,000 rural landholders who submitted their personal accounts to the 1934 Commission of Inquiry into the closer settlement scheme's

59 A. Curthoys, 'Expulsion, Exodus and Exile in White Australian Historical Mythology', Journal of Australian Studies 23 (1999): 1-19, doi.org/10.1080/14443059909387469; A. Moreton-Robinson, 'I Still Call Australia Home: Indigenous Belonging and Place in a White Post-Colonising Society', in Uprootings/Regroundings: Questions of Home and Migration, ed. S. Ahmed et al. (Oxford: Berg, 2003), 23-40; E. Potter, 'Climate Change and Non-Indigenous Belonging in Postcolonial Australia', Continuum 27 (2013): 30-40, doi.org/10.1080/10304312.2013.737197. 
progress. Written mostly by men, as well as a handful of widowed women, these forms and letters offer Cook an insight into the gendered experience of agrarian settlement in an unfamiliar environment, the subtropics of northern Australia. For most of the correspondents, the reality of farming tested their ability to meet the prevailing expectations of rural settler manhood as a stoic provider who could subdue the land. Sharing a similar approach to Parsons and Fisher, Cook studies the how material conditions of the Callide Valley circumscribed the farmers' performance of hegemonic masculinity to their personal detriment.

The final contribution to this collection examines the gendered relationships of refugees to place and environments in urban and rural Australia in the twentyfirst century. Drawing on interviews with Afghani Hazara refugees in Sydney and Wagga Wagga, New South Wales, Heather Goodall and Latifa Hekmat consider the ways in which their experiences constitute a 'gendered flight', owing to the starkly different nature of the journeys that women and men face once they leave their places of origin. Their article's focus is the gendered experience of forced migrancy in relation to water, both in terms of the informant's flight as well as in terms of making place and homes in south-eastern Australia. These accounts reveal the enduring significance of water to the Hazara narrators for whom it represents danger, survival, grief and purification, and sustains the social and affective ties between peoples, places and the past.

The approaches and methods demonstrated here point to how some environmental historians are excavating the power relations of the past to reveal the gendered ways in which non-Indigenous peoples have shaped environments, and been shaped by them in return, as they sought to belong in the settler lands of Aotearoa New Zealand, Australia and Canada since the mid-nineteenth century. Recasting the making of settler places in terms of their gendered production and experience not only enriches their own environmental history, we argue, but also broadens the historian's enquiry to encompass the other lands implicated in the production of settler places. Revitalising gender analysis in environmental history reflects an ethics of scholarship attentive to the importance of the past to addressing increasingly urgent questions of environmental justice in a time of planetary crisis.

\section{Acknowledgements}

The articles in this special issue are drawn from a workshop held on the unceded lands of the Wurundjeri peoples in Melbourne, and of the Dja Dja Wurrung peoples at La Trobe University's Bendigo campus in December 2018. Co-convened by Katie Holmes (La Trobe University) and Ruth Morgan (then at Monash University), the workshop was titled 'Placing Gender: A Workshop on Gender and Environmental History'. The editors are grateful for the productive and friendly 
conversations that arose from the meeting, and Ruth thanks Margaret for joining her in co-editing this set of essays. This gathering of scholars from around the world was only possible with the generous support of the Centre for the Study of the Inland, La Trobe University; the Rachel Carson Center for Environment and Society, Ludwig-Maximilians University, Munich; the Australian Research Council (DE160101125); and the Faculty of Arts, Monash University. The editors also acknowledge the generous contribution of referees whose feedback strengthened the individual articles and the special issue as a whole. Finally, the editors thank James Beattie, Austin Gee and the School of History, The Australian National University, for supporting the publication of this special issue. 
This text is taken from International Review of Environmental History, Volume 7 , Issue 1, 2021, edited by James Beattie, Ruth Morgan and Margaret Cook, published 2021 by ANU Press, The Australian National University, Canberra, Australia.

doi.org/10.22459/IREH.07.01.2021.01 